\title{
DESENVOLVIMENTO DE METODOLOGIA PARA APLICAR TÉCNICAS DO PALEOMAGNETISMO EM ANOMALIAS MAGNETOMÉTRICAS EM CROSTA CONTINENTAL: APLICAÇÃO A ANOMALIAS BRASILEIRAS
}

\author{
Renato Cordani \\ Orientador: Dr. Wladimir Shukowsky (IAG/USP) \\ 110 p. - Tese (Doutorado) - Defesa 28.04.2008
}

RESUMO. 0 presente trabalho apresenta uma nova metodologia multidisciplinar que é capaz de estimar a idade de uma rocha-fonte a partir de sua anomalia magnética apenas, usando dados magnetométricos aéreos ou terrestres. Parte-se de anomalias magnéticas preferencialmente isoladas, e cuja componente remanescente seja provável em função do formato da anomalia. A partir dela calculamos a direção total da magnetização e estudamos as possíveis razões entre as componentes induzidas e remanescentes. Posteriormente, determinamos o segmento de reta que congrega todos os paleopólos virtuais possíveis, e finalmente relacionamos esse segmento de reta à curva de Deriva Polar Aparente da placa tectônica na qual a anomalia está hospedada. Aplicamos diversos testes de consistência na metodologia criada, usando exemplos sintéticos e reais, nas placas Sulamericana e Australiana. Finalmente, aplicamos a metodologia em cinco (5) conhecidas anomalias do território brasileiro, produzidas por complexos alcalinos de idade Mesozóica. As idades aparentes obtidas através da metodologia criada em três das anomalias cujas idades radiométricas são bem conhecidas - Tapira, Araxá e Juquiá - são similares às idades publicadas. As idades aparentes obtidas através das outras duas anomalias cuja idade radiométrica é desconhecida - Registro e Pariqueraçu - foram coerentes relativamente ao contexto geológico. Espera-se que a aplicação da metodologia ora criada possa contribuir para o conhecimento geológico das rochas fontes de anomalias magnéticas da Crosta Continental, especialmente nos casos em que as rochas sejam desconhecidas, cobertas por sedimentos ou não adequadamente amostradas.

ABSTRACT. The present work is a new multi-disciplinary methodology that estimates the age of a source rock from its magnetic anomaly only, taken directly from the airborne or ground magnetic data. The idea is to use those anomalies in which a strong remanent magnetic component is likely to occur, calculate from the magnetic anomaly the total magnetization and study the possible ratios between induced and remanence. Next, the line segment linking all virtual paleogeographic poles of this anomaly will be built, and finally this segment will be related with the position, on a paleogeographic projection, of the appropriate age fragment of the APWP curve. We ran several applications to test the efficiency of the methodology, both using synthetic and real examples. Tests were performed in two different tectonic plates, South American and Australian. Finally, we applied this procedure on five (5) well known magnetic anomalies of the South American plate, produced by alkaline complexes of Mesozoic age. The apparent ages obtained from the methodology application on three of the anomalies, where the radiometric age of the source rock is known - Tapira, Araxá and Juquiá - were reasonably close to the published ages. The apparent ages of the other two, obtained from anomalies in which the age of the source rock is not known - Registro and Pariqueraçu magnetic anomalies - were coherent relative to the geologic context. We expect that the application of the developed methodology as a reconnaissance geochronological tool may contribute to geological knowledge over continental areas, especially when the source rocks of the magnetic anomalies are unknown or buried below superficial sediments. 